\title{
PENGEMASAN DAN PENJUALAN ONLINE PRODUK HORTIKULTURA GUNA MENJAMIN USAHA PADA SAAT PANDEMI COVID-19
}

\author{
Agung Prasetyo $^{1 *}$, Sutarno², Mahananto ${ }^{3}$, Teguh Supriyadi ${ }^{4}$, Eko Hartoyo 5 \\ ${ }_{1,2,3,4}$ Universitas Tunas Pembangunan Surakarta \\ Email Korespondensi: agungpras17@gmail.com
}

\begin{abstract}
ABSTRAK
Kasus positif COVID-19 di Indonesia pertama kali dideteksi pada 2 Maret 2020 dan sampai saat ini sudah menyebar ke seluruh provinsi yang ada. Kendala utama yang menjadi permasalahan utama akibat covid-19 adalah kendala logistik dalam rantai pasokan, khususnya gangguan dalam pasokan pangan. Apabila kendala ini terjadi dalam jangka panjang, komoditas yang mudah rusak seperti buah-buahan dan sayur-sayuran segar dampak secara masif. Desa Berjo di Kecamatan Ngaroyoso sebagai penghasil sayuran harus bersiap menghadapi dampak covid-19 yang sudah memasuki wilayah Kabupaten Karanganyar. Strategi perbaikan kemasan dan beralih menggunakan media online sebagai media promosi dan pemasaran dirasa tepat untuk bertahan disituasi pandemi. Jumlah peserta sebanyak 10 orang sesuai anjuran protokol kesehatan di Desa Berjo yang sebagian besar adalah ibu rumah tangga. Metode yang digunakan yaitu pelatihan dan pendampingan. Hasil dari pelatihan ini adalah meningkatnya pengetahuan dan kemampuan peserta dalam pengemasan dan penyimpanan produk dan pemanfaatan sosial media sebagai alat pemasaran, yang ditunjukkan dengan perubahan angka rerata pretest dan posttes, yaitu dari skor 80,29 ke skor 99,30. Strategi ini diharapkan mampu menjadikan usaha dapat bertahan disituasi pandemi dan bahkan memperluas wilayah pemasarannya.
\end{abstract}

Kata kunci: pelatihan, pengemasan dan jual beli online, sosial media

\begin{abstract}
The positive case of COVID-19 in Indonesia was first detected on March 2, 2020, and until now it has spread to all existing provinces. The main obstacle that becomes the main problem due to COVID-19 was logistical constraints in the supply chain, specifical disruptions in the food supply. If this obstacle occurs in the long term, perishable commodities such as fresh fruits and vegetables will have a massive impact. Berjo Village in Ngaroyoso District as a vegetable producer must be prepared to face the impact of COVID-19 which has entered the Karanganyar Regency. The packaging improvement strategy and switching to using online media as a media for promotion and marketing was considered appropriate to survive a pandemic situation. The number of participants as many as 10 people according to the recommended health protocol in the village of Berjo, mostly are housewives. The method used was training and assistance. The results of this training were the increase in participants' knowledge and ability in product packaging and storage and the use of social media as a marketing tool, as indicated by changes in the mean pretest and posttest, from 80.29 to 99.30 . This strategy was expected to make a business able to survive in a pandemic situation and even expand their marketing territory.
\end{abstract}

Keywords: training, packaging and buying and selling online, social media. 


\section{PENDAHULUAN}

Pandemi Corona Virus Disease 2019 (COVID-19) diumumkan WHO (World health Organization) tanggal 11 Maret 2020. Pandemi Covid-19 muncul pertama kali pada 31 Januari 2020 di Wuhan, Propinsi Hubei, RRC. Memasuki pertama Bulan Juli 2020 terdapat 10.857.346 korban positif yang diantaranya terdapat korban jiwa sebesar 520.127 meninggal dunia dan dinyatakan sembuh sebanyak 6.076.094 orang (Worldometer, 2020). Kasus positif COVID-19 di Indonesia pertama kali dideteksi pada 2 Maret 2020. Pada 2 Juli, pandemi sudah menyebar ke 34 provinsi dengan Provinsi Jawa Timur, DKI Jakarta, dan Sulawesi Selatan sebagai provinsi paling terpapar (Ratcliffe, 2020)

Dampak Covid-19 terhadap perekonomian China yang timbul akibat Covid-19 yang diikuti kebijakan lockdown Kota Wuhan telah mengurangi dan bahkan menghentikan beragam aktivitas masyarakat hingga menyebabkan terjadi penurunan angka pertumbuhan ekonomi turun jauh hingga menyentuh angka 2\% pada capaian sebelum pandemi Covid-19 (Khan \& Faisal, 2020) Di Indonesia, Provinsi Jawa Timur khususnya Surabaya dan DKI Jakarta yang merupakan pusat perputaran bisnis di Indonesia sebagai pusat pandemi telah menerapkan kebijakan social distancing, work from home (WFH) dan pembatasan sosial berskala besar (PSBB) bagi para aparat pemerintahan daerah, perusahaan, sektor pendidikan dan pengurangan intensitas transportasi publik untuk mencegah penyebaran virus semakin meluas. Kehadiran dan cara transmisi penyebaran pandemi Covid-19 dinilai berkontribusi menentukan survive tidaknya entitas bisnis dalam menjalankan usahanya (Taufik \& Ayuningtyas, 2020). Kendala utama yang menjadi permasalahan utama akibat covid-19 adalah kendala logistik dalam rantai pasokan, khususnya lintas batas dan pembatasan pergerakan dalam negeri, serta persoalan ketenagakerjaan, dapat mengakibatkan gangguan dalam pasokan pangan apabila kendala ini terjadi dalam jangka panjang. Komoditas bernilai tinggi, dan khususnya yang mudah rusak, seperti buah-buahan dan sayur-sayuran segar, daging, ikan, susu dan bunga akan terkena dampak secara masif (ILO, 2020). Protokol kesehatan yang diterapkan sekarang ini juga mewajibkan pelaku bisnis untuk membenahi kemasan barang yang dihasilkan agar produk yang dipasarkan terjamin keamanannya bagi konsumen, tidak terkecuali bagi bisnis produk segar seperti sayuran dan buah-buahan.

Kabupaten Karanganyar merupakan salah satu wilayah sentra penghasil komoditas sayuran di Jawa Tengah yang juga terkena paparan virus covid-19 meskipun sampai dengan awal Bulan Juli masih tergolong rendah. Sentra pengahasil sayur di Kabupaten Karanganyar berada di Kecamatan Tawangmangu, Karangapandan, Matesih, Jenawi, Jumapolo dan Ngargoyoso. Salah satu desa penghasil sayuran di Kecamatan Ngargoyoso. adalah Desa Berjo. Hasil wawancara dengan sekertaris desa didapatkan bahwa mayoritas penduduk Desa Berjo berkerja sebagai petani dan buruh memiliki tingkat pendapatan rata-rata tergolong rendah. Umumnya petani menjual produk dalam bentuk segar dan istri dari petani atau buruh tersebut tidak mempunyai pekerjaan tetap selain mengurus rumah tangga dan bekerja sebagai pedagang di pasar maupun diberbagai tempat wisata di Kecamatan Ngargoyoso. Masalah tersebut menjadi semakin rumit 
melihat situasi sekarang dengan merebaknya pandemi Covid-19. Pandemi Covid 19 memaksa seluruh sektor untuk melakukan transaksi perdagangan secara online, tidak terkecuali bisnis dibidang pertanian. Jika sebelum pandemi petani bebas untuk tidak mengemas produknya dan berdagang secara bebas dipasar, setelah pandemi seperti sekarang guna menekan penyebaran pandemi model usaha dan perdagangan semacam itu akan bermasalah sementara petani maupun istri petani tersebut belum pernah untuk melakukan transaksi lewat online.

Tujuan dari pengabdian dilakukan sesuai dengan kebutuhan adalah untuk meningkatkan kualitas kemasan produk sayuran sesuai dengan standar keamanan pangan dan konsep penyimpanan yang baik. Pengabdian ini juga dilakukan untuk meningkatkan kemampuan dan ketrampilan untuk melakukan jual beli secara online.

\section{METODE}

Metode yang digunakan adalah sosialisasi dan pelatihan terhadap peserta / mitra sejumlah 10 orang dengan menjaga dan menerapkan protokol kesehatan dalam suasana covid-19. Kegiatan dimulai dengan mengidentifikasi tingkat pengetahuan dan tingkat ketrampilan peserta tentang kemasan dan melakukan jual beli online utamanya melalui sosial media dengan cara melakukan tanya jawab antara trainer (pelatih) dengan peserta. Setelah dilakukan tanya jawab, peserta diberikan sosialisasi tentang bagaimana cara pengemasan sayuran yang baik dan mempromosikan produknya melaluli pemasaran digital khususnya melalui sosial media. Sosialisasi kemudian dilanjutkan dengan pelatihan tips dan trik berjualan secara online kemudian dilanjutkan dengan pelatihan dengan materi cara membuat akun, melakukan edit foto dan mengunggah ke dalam akun, serta memberikan respon ke konsumen.

\section{HASIL DAN PEMBAHASAN}

Sosialisasi dilakukan untuk mengedukasi peserta tentang peran penting kemasan dan sistem pemasaran secara online. Sosialisasi meliputi fungsi kemasan yang diantaranya melindungi dan mengawetkan produk, seperti melindungi dari sinar ultraviolet, panas, kelembaban udara, benturan serta kontaminasi kotoran dan mikroba yang dapat merusak dan menurunkan mutu produk serta virus yang ada diluar, kemudian sebagai identitas produk, dalam hal ini kemasan dapat digunakan sebagai alat komunikasi dan informasi kepada konsumen melalui merk yang tertera pada kemasan dan kemasan meningkatkan efisiensi, seperti memudahkan proses penghitungan pengiriman dan penyimpanan produk (Mukhtar \& Nurif, 2015). Merespon terhadap adanya pandemi covid-19 pelatihan ditujukan untuk mengemas produk untuk tujuan konsumsi rumah tangga secara langsung. Efek adanya pembatasan sosial banyak menjadikan konsumen enggan untuk bepergian keluar rumah. Strategi direct selling menjadi pilihan yang baik untuk memastikan usaha berjalan dengan baik. Strategi ini akan lebih efektif jika dikembangkan bersamaan dengan pemasaran online lewat sosial media Berikut adalah gambar perbaikan kemasan sebelum dan sesudah dilakukan sosialisasi dan pelatihan: 


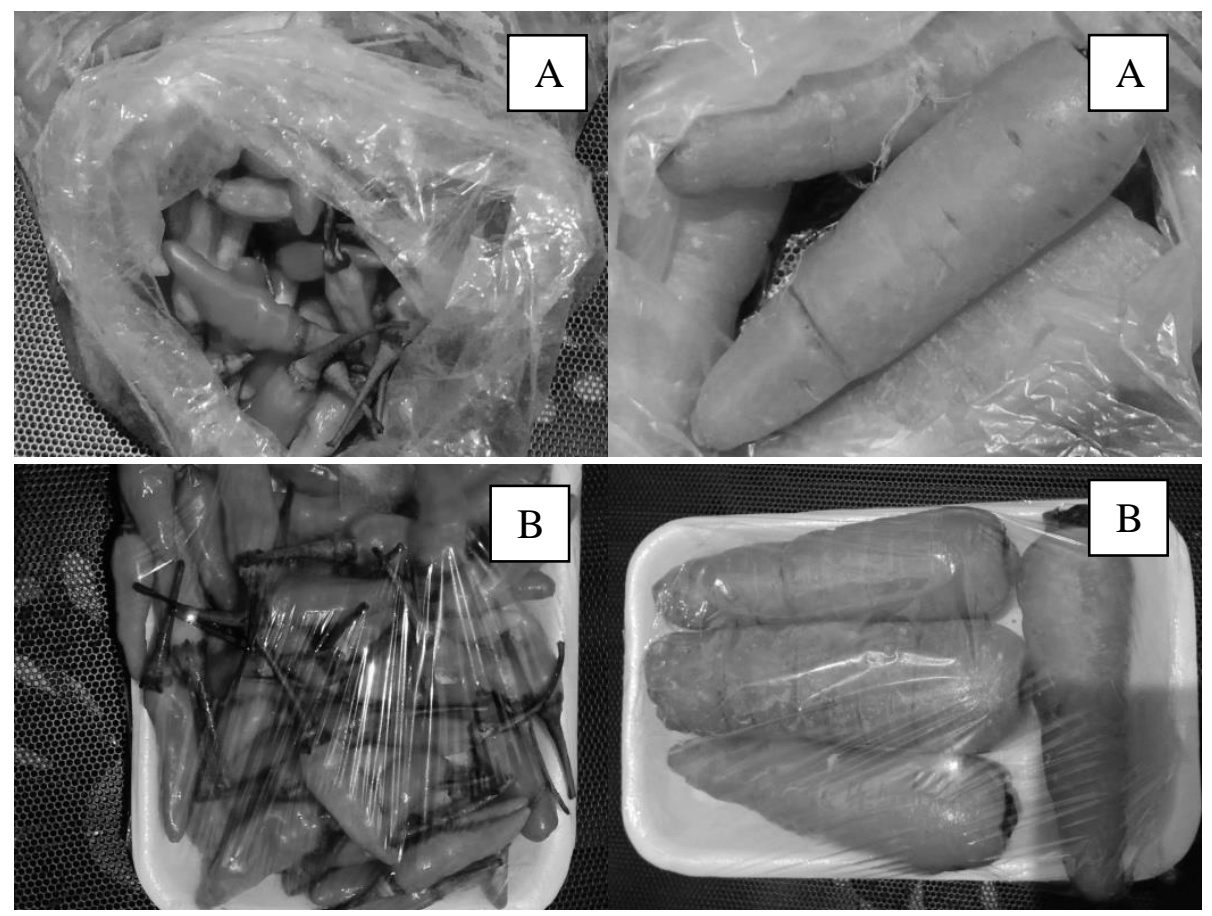

Gambar 1. Produk Sebelum (A) dan Sesudah (B) Dilakukan Perbaikan Kemasan

Sosialisasi juga dilakukan dengan memberitahukan pentingnya internet utamanya sosial media, yang berperan dalam pertukaran informasi tanpa terhambat oleh batas ruang dan waktu (Werdani, Kurniawati, Sukoco, Windriya, \& Iskandar, 2020). Sebelum kegiatan hanya 40\% orang yang sudah mempunyai akun facebook dan hanya $10 \%$ yang mempunyai instagram sementara semuanya sudah memiliki akun whatsapp. Akun online shop seperti shopee bukalapak, tokopedia dll belum ada yang mempunyai. Setelah kegiatan dilakukan 90\% orang sudah mempunyai akun facebook dan instagram karena sisanya berasal dari keluarga yang sama sehingga hanya membutuhkan satu orang. Kemudian dalam kelompok tersebut hanya membuat satu akun di shopee.

Penerapan sosial media facebook lebih besar daripada Instagram. pengguna facebook di Indonesia menempati urutan ketiga sebesar $81 \%$ sedangkan Instagram menempati urutan keempat yaitu $80 \%$. Sehingga mereka lebih mudah memahami fitur-fitur di facebook daripada di instagram (Werdani et al., 2020). Sementara dengan whastapp peserta tidak mengalami kesulitan sama sekali karena dengan mudah membuat dan mempromosikan lewat fitur status whatsapp dan broadcast message.

pelatihan dilaksanakan dengan menggunakan metode experiential learning, yaitu melibatkan peserta secara aktif di setiap sesi pelatihan sehingga peserta belajar dan mengalami secara langsung setiap proses selama pelatihan. Kegiatan ini dilakukan dengan metode ceramah, tanya jawab, demonstrasi dan praktek langsung. berikut adalah contoh akun pribadi dari peserta: 
GANESHA: Jurnal Pengabdian Kepada Masyarakat

Vol. 1, (1) Januari 2021

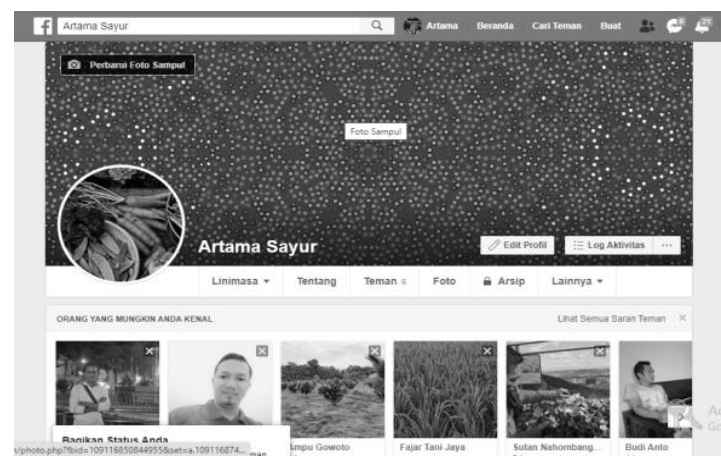

Gambar 2. Akun Facebook peserta

Kemudian pelatihan dilakukan dengan mengedit foto dan mengunggahnya di sosial media membuat konten bisnis di sosial media melalui marketplace facebook dan caption pada instagram. Contoh tampilan konten produk dapat dilihat berikut ini:
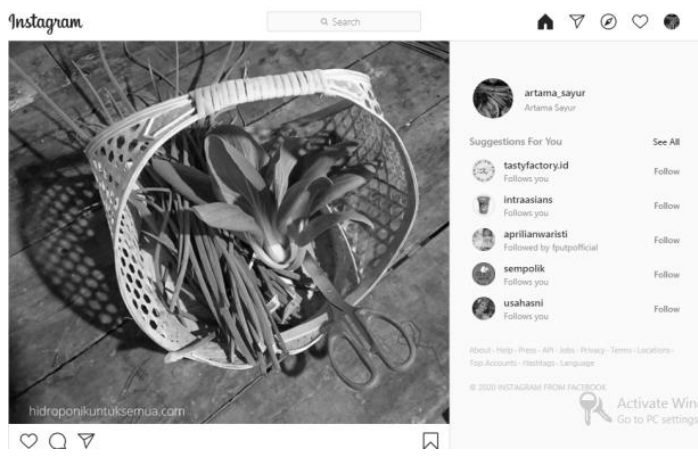

Gambar 3. Caption di Instagram

Pelatihan cara berkomunikasi dengan pelanggan melalui whatsapp, facebook dan Instagram diberikan dengan cara mempromosikan produk ke konsumen agar lebih menarik dan cara merespon pesan dari konsumen yang baik dan benar. Berdasarkan observasi langsung keberhasilan pelatihan ini dipengaruhi oleh banyak hal, antara lain kompetensi trainer dalam memberikan materi, kelengkapan sarana dan peralatan untuk melakukan praktek. Kemudian terakhir akun shopee dibuat untuk memberikan gambaran jual beli melalui platform tertentu. Berikut akun shopee yang dibuatkan satu untuk perkelompok dengan harapan satu akun dapat melayani seluruh kebutuhan kelompok dalam transaksi jual beli melalui platform mengingat ketersediaan produk dari mitra dan keterbatasan stok barang yang diproduksi.

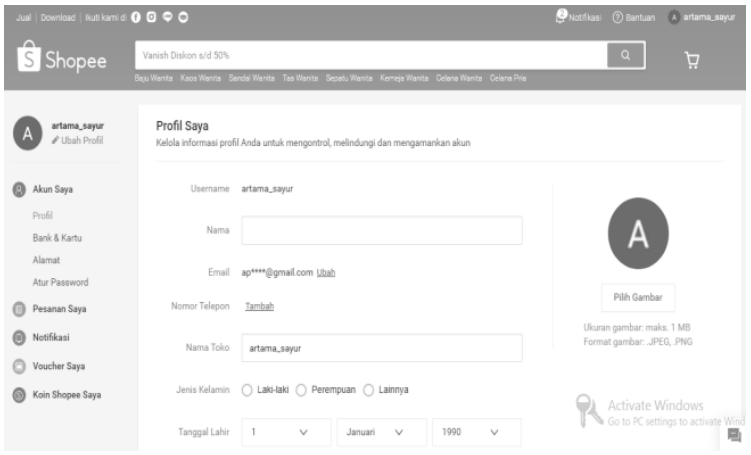




\section{Gambar 4. Akun Shopee}

Berdasarkan hasil analisis dari uji pretest dan posttest yang dilakukan terhadap peserta didapatkan hasil nilai sig $(2$-tailed $)=0,029$ dengan taraf signifikansi $0,002(\mathrm{p}<0,05)$ skor rerata pretest 80,03 menjadi skor rerata posttest 99,30. Perubahan menunjukan adanya perubahan tingkat pemahaman dan keterampilan menggunakan media sosial sebagai alat pemasaran produk. Peserta pelatihan terlihat aktif dan sesekali memberikan pertanyaan. Evaluasi pelatihan yang terdiri dari evaluasi terhadap materi pelatihan, trainer atau pelatih. Menurut peserta pelatihan, materi yang diberikan sesuai dengan kebutuhan untuk bertahan disituasi pandemi covid-19.

\section{KESIMPULAN}

Pelatihan perbaikan kemasan dan pemasaran produk melalui sosial media yang telah dilaksanakan mampu meningkatkan pengetahuan dan kemampuan peserta dalam mengemas produknya agar lebih menjamain keamanan pangan bagi konsumen dan peserta mampu memanfaatan sosial media sebagai alat jual beli online. Dengan menggunakan media sosial sebagai alat pemasarannya diharapkan tetap mampu meraih pasar bahkan memperluas pasar guna menjamin keberlangsungan usaha pada saat pandemi covid-19.

\section{UCAPAN TERIMA KASIH}

Terimakasih kepada Bapak Mulyanto selaku mitra kegiatan Pengabdian pada Masyarakat Desa Berjo, Kecamatan Ngargoyoso, Kabupaten Karanganyar yang telah mengikuti kegiatan pengabdian masyarakat. Terimakasih kepada segenap pihak-pihak yang telah membantu dalam proses kegiatan pengabdian pada masyarakat ini.

\section{DAFTAR PUSTAKA}

ILO. (2020). Risalah Sektoral ILO: COVID-19 dan dampaknya terhadap pertanian dan ketahanan pangan. International Labour Organization, (17 April 2020), 1-8.

Khan, N., \& Faisal, S. (2020). Epidemiology of Corona Virus in the World and Its Effects on the China Economy. SSRN Electronic Journal. https://doi.org/10.2139/ssrn.3548292

Mukhtar, S., \& Nurif, M. (2015). Peranan Packaging Dalam Meningkatkan Hasil Produksi Terhadap Konsumen. Jurnal Sosial Humaniora, 8(2), 181. https://doi.org/10.12962/j24433527.v8i2.1251

Ratcliffe, R. (2020). First coronavirus cases confirmed in Indonesia amid fears nation is illprepared for an outbreak.

Taufik, T., \& Ayuningtyas, E. A. (2020). Dampak Pandemi Covid 19 Terhadap Bisnis Dan Eksistensi Platform Online. Jurnal Pengembangan Wiraswasta, 22(01), 21. https://doi.org/10.33370/jpw.v22i01.389

Werdani, R. E., Kurniawati, N. I., Sukoco, J. B., Windriya, A., \& Iskandar, D. (2020). Pelatihan Pemasaran Produk Homemade Melalui Sosial Media. JPPM (Jurnal Pengabdian Dan Pemberdayaan Masyarakat), 4(1), 1. https://doi.org/10.30595/jppm.v4i1.4655

Worldometer. (2020). Reported Cases and Deaths by Country, Territory, or Conveyance. Retrieved from https://www.worldometers.info/coronavirus/ 